\title{
la incrustación de la alúmina y la magnesia en el silicato tricálcico
}

\author{
die einlagerung von $\mathrm{Al}_{2} \mathrm{O}_{3}$ und $\mathrm{MgO}$ in tricalciumsilikat \\ F. W. LOCHER
}

(«Zement-Kalk-Gips», 13, núm. 9, septiembre 1960, pág. 389.)

Se han tratado a $1.500^{\circ} \mathrm{C}$ mezclas de silicato tricálcico y aluminato tricálcico, enfriando después rápidamente. La composición del producto fundido queda determinada por el punto invariante $\mathrm{D}\left(1.470^{\circ} \mathrm{C}\right)$ del sistema $\mathrm{CaO}-\mathrm{Al}_{2} \mathrm{O}_{3}-\mathrm{SiO}_{2}$. Puesto que este material fundido es relativamente pobre en cal $\mathrm{y}$, a consecuencia del rápido enfriamiento, no puede reaccionar con las fases sólidas $\mathrm{C}_{3} \mathrm{~S}$ y $\mathrm{CaO}$, la mezcla debe contener una cierta cantidad de cal libre, a pesar de que los componentes $\mathrm{C}_{3} \mathrm{~S}$ y $\mathrm{C}_{3} \mathrm{~A}$ de la mezcla inicial no contienen prácticamente cal libre. La presencia de cal libre indica, por tanto, que la muestra calentada contiene una fase líquida.

Además, como la masa fundida está constituída, esencialmente, por el aluminato que no se ha incorporado en el $\mathrm{C}_{3} \mathrm{~S}$, es posible determinar cuánto $\mathrm{C}_{8} \mathrm{~A}$ puede absorber, como máximo, el $\mathrm{C}_{3} \mathrm{~S}$, determinando el contenido de cal libre por análisis químico.

Los ensayos demostraron que el valor límite se halla alrededor de $2 \%$ de $\mathrm{C}_{3} \mathrm{~A}$, que corresponde a $0,7-0,8 \%$ de $\mathrm{Al}_{2} \mathrm{O}_{3}$. Los átomos de aluminio incorporados ocupan los lugares de los átomos de silicio. Los ensayos por rayos $\mathrm{X}$ han demostrado que las dimensiones de la red de $\mathrm{C}_{3} \mathrm{~S}$ no se altera, o lo es sólo ligeramente, al incorporar el $\mathrm{C}_{3} \mathrm{~A}$.

Los iones magnesio pueden reemplazar a los iones calcio en la red del silicato tricálcico; estos iones calcio se les encuentra en las mezclas cocidas como $\mathrm{CaO}$ libre. Determinando el contenido en cal libre se ha visto que el $\mathrm{C}_{3} \mathrm{~S}$ puede absorber hasta $1,5 \%$ de $\mathrm{MgO}$ a $1.420^{\circ} \mathrm{C}$ y hasta $2,5 \%$ a $1.500^{\circ} \mathrm{C}$, aunque incluso contenga el $\mathrm{C}_{3} \mathrm{~S}$ un $4 \%$ de $\mathrm{C}_{3} \mathrm{~A}$. Por introducción de $\mathrm{MgO}$, la red de $\mathrm{C}_{3} \mathrm{~S}$ se retrae.

La estabilidad de silicato tricálcico y de la alita se disminuye notablemente por debajo de $1.250^{\circ} \mathrm{C}$ en presencia de $\mathrm{MgO}$. El aluminato tricálcico, por el contrario, no tiene más que una débil influencia que no ha podido determinarse con exactitud. 